\title{
Who are Tomorrow's Foresters and What do They Want? A Sociologist Looks at Two Forestry Schools
}

\author{
by
}

Jan Mayer, Ph.D. ${ }^{1}$

\begin{abstract}
A survey of first and final year students at the UBC and Lakehead Schools of Forestry suggests that forestry students are much more idealistic about their profession and less materialistic than they are generally given credit for, particularly when compared with students in engineering or business administration. Whether or not their idealism will greatly influence the forestry world of the future will depend on how effectively they learn to communicate, public understanding and support on forestry issues, and the ability of professional associations to enhance the influence and visibility of the profession.
\end{abstract}

\section{Résumé}

Une enquête effectuée auprès des étudiants de première et de dernière années des Facultés de Foresterie à UBC et de Lakehead, suggère que les étudiants en foresterie ont une vision beaucoup plus idéaliste de leur profession et moins matérialiste qu'on pourrait le croire, particulièrement lorsqu'on les compare aux étudiants en génie ou en administration des affaires. Leur degré d'influence dans le monde forestier, d'après leurs idéaux dépendra largement de comment ils auront appris à communiquer, à comprendre les interventions publiques soulevant la contreverse en foresterie et de la capacité des associations professionnelles à augmenter l'influence et la représentativité de la profession.

\section{Introduction}

Will tomorrow's foresters be part of the solution or part of the problems in the forest? The good management of our forests depends in part on our future forestry professionals. We may say only "in part"' because there are many constraints on foresters' decision-making control - some are political, affected by government policy and by the relationship between government and industry; the other constraints are provided by one of the most dynamic action environments faced by professional practitioners, that of nature itself.

At a time when many regard the problems of forest management to be of unprecedented severity, many thoughtful people wonder what kinds of qualities future foresters must have to contribute effectively to their solution. Some forestry academics believe that the power exercised by foresters and their professional associations is still very low, that it must be increased if they are to be an effective voice for change, and that they must become more publicly visible. Other academics interested in the interface between forestry and other social issues have suggested that the teaching of solutions must not be merely technocratic, not just integrative of theoretical knowledge, but sensitive to the sociological and psychosocial dimensions of problems (see for example Wenner 1986, Miller 1982). Many within forestry have remarked that the "old-style" forester who is only interested in talking to the trees must be replaced with a "new style" of forester effective in communication and sensitive social issues.

Department of Sociology, Lakehead University, Thunder Bay, Ontario P7B 5E1
Do today's forestry students possess this potential? How are they motivated, and how aware are they of the sociopolitical environment in which forestry operates?

\section{A Forestry School Survey}

During the 1980's many university teachers observed that the new crops of students were by and large less radical, less open to experiences that contradicted their view of the world, less idealistic, and more interested in what university could do for them in the job market, than their predecessors of the 1960's and 1970's. As a sociologist, I was interested not only in the extent of their idealism, but also in their values and orientations especially as these applied to questions of professional awareness. Between 1983 and 1986, I studied the attitudes of forestry school students at Lakehead University and the University of British Columbia, in two heavily forested areas of Canada that have received much critical attention during the past few years. Altogether, 166 students in the first and final years of their programme were surveyed, with additional comparative background data being supplied by a sample of faculty respondents.

This article reports on the main findings of that study. Although only a relatively few students were involved, the similarity between the two student bodies and their similarity to students surveyed at Berkeley (see Teeguarden 1984) suggest a current trend that could well be representative of all forestry students in Canada. The study, therefore, has implications for our understanding of our future foresters, and of the contradictory elements in their beliefs which could be problematical. 


\section{Social Background Experiences}

Forestry students were overwhelmingly young, male, and middle class in background. Female enrollment has increased materially over the past five years, particularly compared with engineering where it is negligible. Nevertheless, forestry enrollment is still $81 \%$ male, suggesting that it has not become a popular career choice for women.

The numbers of both sexes who have attended community college or technical school before beginning university has increased, but $67 \%$ of first-year students are 18-20 years old and entry out of high school is still quite usual. Despite their youth, however, $60 \%$ of those surveyed had parttime work experience, some even had full-time experience, and almost two-thirds of this experience was in outdoor work, some of it directly in the forest (a common occurrence especially for those with a rural background).

This exposure to the outdoors seems to be an important feature in career choice shared by many students despite their differing backgrounds and is surprising, given the fact that $20 \%$ more of the students come from central metropolitan areas than from forested areas. The interest in the outdoors, combined with an interest in science, is also a dominant pattern for forestry faculty, so the students are very similar to their mentors.

Also like their teachers, $77 \%$ of the students are of middle-class families, many with professional and managerial fathers (and $20 \%$ of the mothers are also employed as professionals). Thus the students come from comfortable home environments where typically, material and cultural resources are available and where occupational success is a realistic expectation.

How interested are these students in forestry? The evidence suggests that forestry students by and large have not arrived in their programmes by default. Most had reported aspiring to a forestry career while in mid to late high school, and although many had applied to other forestry schools before coming to their present programme, only one-quarter had applied to other science programmes (mainly biology and environmental science), and only a mere $10 \%$ had applied to any non-science programmes. Since only a third of the students reported any family member or close family friend in forestry, we may assume that the influence came from elsewhere, including exposure to the outdoors, outdoor work, and environmental concerns, as we shall see when we examine their values and orientations.

\section{Work Values and Motives}

Students were asked why they wanted to go into forestry, and their responses were then categorized by general thematic content (see Table 1). A few had purely "instrumental" motives, wherein forestry was only a means to good pay, job security or opportunities, or prestige and power. Most had the more altruistic motive of wishing to contribute to the management or conservation of a resource so important to society, or who had a knowledge and love of the field and outdoors. Altogether, $26 \%$ expressed some variation on the service ethic and $19 \%$ stressed love of the outdoors. These idealists comprised half of those surveyed. Another $27 \%$ said they were motivated by interest in a field that they believed would be satisfying and challenging.

In a similar survey of engineering and business students, far more had instrumental or mixed motives and those with idealistic commitment to the field were far fewer. Forestry students therefore are a highly motivated group, especially noteworthy at a time when students are aware of declining job markets and often opportunistically enter fields where they believe job prospects are greater.

\begin{tabular}{lr}
\hline Table 1. Why did you choose to enter forestry? & \\
\hline 1. Interest, challenge, satisfaction etc. & $27 \%$ \\
2. Managing/conserving socially important resource & $26 \%$ \\
3. Knowledge, love of field and/or outdoors & $19 \%$ \\
4. Mixed motives (interest etc., plus money, etc.) & $15 \%$ \\
5. Instrumental motives (money, promotion, power, etc.) & $12 \%$ \\
6. Other (unclassifiable) & $1 \%$ \\
\hline
\end{tabular}

When the students were asked what aspects of work they valued most, the usual responses were: chance to use and develop one's abilities, followed by the desire for autonomy or independence in doing the job. These two items accounted for $80 \%$ of responses for first-ranked features of work; status ranked very low as a valuable aspect. Nevertheless, prospective foresters recognize that the scope a job allows for using abilities and being independent is often linked to advancement, and so, a third of the students realistically chose opportunity to advance as second in importance, while pay itself actually ranked almost as low as status (see Table 2).

\section{Table 2. Valued aspects of work*}

(a) Ranked as most important:

\section{Use/develop abilities}

Autonomy/independence

(b) Ranked as second most important: Autonomy/independence Advancement opportunity

(c) Ranked as least important:

$$
\text { Status }
$$

-Students were asked to order in rank five factors: pay, status, advancement, abilities, independence. \%'s reported are aggregated data for dominant responses in highest and lowest ranking categories.

Foresters may be a particularly unmaterialistic group of idealists, but the current trend towards the limited contract form of employment is viewed by students as a problem, not only for its implications in using abilities on an ongoing basis but also for its lack of security, and many of them are worried about establishing themselves in a career. Undoubtedly, this insecurity of employment could also affect their willingness to speak out if they see instances of resource mismanagement.

When some of the students were interviewed, many were found to have definite ideas of what they want down the road in their careers, given that they can retain the qualities of work that are valuable to them. Although most admit that the appeal of outdoor work for the next 20 years would decline along with physical ability to put up with difficulties such as cold or insects, yet their idea of advancement does not include administrative work that would carry them away from forestry. Unlike many engineers, they are not much interested in using their field as a stepping-stone to the general manager's office. Thirty per cent of the students interviewed aspired to a managerial position that would allow them to keep in touch with the resource and to make planning decisions and effect change in it. Another $20 \%$ were interested in research, and $20 \%$ considered consulting or other self-employment in the future. The remaining $30 \%$ were unsure or unclear, having not looked too far beyond getting their first job after graduation. 


\section{Perceptions of the Profession}

Respondents were asked to define forestry and to state their criteria for judging forestry to be a profession (Table 3 )..

Over $80 \%$ of the students (and faculty) believed that the label "profession" could be attached to forestry, and $40 \%$ of them based this on the level of knowledge, expertise and credentials required. Another $20 \%$ defined a profession as one requiring not only education but responsibility and commitment. Only $4 \%$ based their judgment on legally mandated powers to practice, including as defined by a professional association and code of ethics (and only $8 \%$ of faculty mentioned this feature). Students' perceptions of what it means to be a professional were dominated by the knowledge criteria, and although the theme of professional responsibility was present, it did not include recognition of the role played by professional associations. Indeed, even among faculty there is considerable doubt expressed as to how effective forestry associations are.

Despite the acknowledgment that forestry is a profession, half the students believed that foresters had very little power, and only $15 \%$ believed professional power was high. Their ineffectiveness was attributed to the far greater power of industry and government.

Consistent with this view, when asked if there were a crisis in the forest, $70 \%$ believed there was (as opposed to $54 \%$ of faculty who believed so). Over one-third felt that the causes included political factors such as inadequate funding of regeneration and research, short-term thinking, use conflicts, the Crown land tenure system, and an inconsistent government stance on forest management. Another third attributed the crisis largely to wood supply problems including overcutting without compensatory regeneration, and only $10 \%$ attributed the crisis to the state of world markets and other economic factors. Thus, the causes of problems in the forest are not seen as primarily technical in nature, but rather owing to factors that so far have been beyond the ability of foresters to influence much, since ultimate decision-making responsibility rests with industry or government. Students feel that foresters have little voice in this and are frequently overruled.

The awareness of professional powerlessness is also evident when students who were interviewed commented on professional conflicts. A frequent remark was that foresters must consider the risk of losing their jobs if they speak up about poor practices and that it is the employer who has the power of the paycheque to dictate conformity to its wishes. The costs of blowing the whistle were apparent to the Lakehead students, who knew of the MacAlpine case (Swift 1983) and agreed with the stand he had taken, even though some could not support his methods.

Students are apparently becoming sensitized to contradictions between the theory and practice of forestry, especially those between learning professional responsibility and the penalties that may come from exercising it.

\begin{tabular}{lr}
\hline Table 3. Defining forestry as a profession. & \\
\hline Based on knowledge, etc. & $40 \%$ \\
Based on responsibility, etc. & $20 \%$ \\
Based on mandated powers, etc. & $4 \%$ \\
Other (unclassifiable) & $13 \%$ \\
No response & $5 \%$ \\
\cline { 2 - 2 } Not a profession & $82 \%$ \\
\hline
\end{tabular}

Another source of tension exists between the official definition of forestry as a discipline and the bias in practice that over-emphasizes economic use of the forest. When students were asked what they believed the main focus or objective of forestry was, $35 \%$ replied: the management of the resource and its lands for a variety of uses that benefit society (the so-called multiple-use philosophy subscribed to by $75 \%$ of faculty). Another $18 \%$ mentioned stewardship of the land for present and future generations, and 13\% combined stewardship with multiple use (Table 4). Only a quarter of the students defined forestry in strictly economic terms, including sustained yield intended only for timber production. For many students, then, their idealistic concern for the forest and their desire to participate in a field of vital social importance is compatible with the official definition of forestry promoted by the forestry schools and the Science Council of Canada for the last decade. There is, however, an inconsistency between the philosophy and the bias towards logging that has caused overcutting and regeneration crises.

\section{Table 4. Main focus of forestry.}

\begin{tabular}{lr}
\hline Multiple-use philosophy & $35 \%$ \\
Stewardship of resource & $18 \%$ \\
Multi-use plus stewardship & $13 \%$ \\
Sustained timber yield & $19 \%$ \\
"Mining" the resource & $4 \%$ \\
Other (management goal unspecified) & $12 \%$ \\
\hline
\end{tabular}

This inconsistency becomes clearer when students were asked a leading question implicitly biassed against multiple use: when human benefit is involved, should economic factors be primary and only those uses considered that can be justified by strict cost-benefit analysis?

Altogether, $58 \%$ of the respondents disagreed with the validity of a strictly economic viewpoint, some more strongly than others, and only $38 \%$ of the students accepted it in some measure (the balance had no opinion). Among students entering their final year, the percentage of those agreeing rose, although they also subscribed to the multiple-use philosophy. Clearly, conflict exists between these outlooks whose potential contradictions have not yet become as apparent to future foresters as have the contradictions between professional responsibility and powerlessness. Ultimately, which model they subscribe to or struggle against will be determined by the kinds of jobs they get.

\section{Images of Tomorrow: Creating a New Legacy?}

The survey has shown that forestry students have a considerable idealism and sense of responsibility in preparing for a field that they are aware of as something of a political football, and the strength of their motivation is high compared with some other professional students. Despite the cynical observations of many professors about the current generation being more narrow-minded and materialistic than their predecessors, Canadian forestry students resemble less the run of the mill and more the students surveyed at Berkeley between 1969 and 1982, especially in their subscription to philosophies of multiple use and stewardship and in their concern over crises of wood supply. Also as in the Berkeley sample, there seem to be unresolved contradictions and tensions within the field that are reflected in doubts about the role of the forester and ambivalance over narrowly economic decision-making.

The forestry schools are producing future practitioners many of whom have the potential to make a thoughtful 
contribution to debates on the forest. These students are well aware that the public image of the forester is the "lumberjack type" or the "forest ranger, Grizzly Adams type". They know that their role encompasses much more, including but not limited to a solid grounding in the application of scientific theory to practical techniques. Two-thirds of the students entering their final year had an image of what the ideal forester should be that went well beyond the stereotypes and well beyond science, perhaps too far beyond for those who would like foresters to remain non-vocal. Students want the forester to be well-rounded, with the ability to integrate creatively and balance quantity and quality, present and future, use and environment, to see beyond the needs simply of the employer to a broader overview. They also believe the forester should be willing and able to speak out about matters of professional responsibility if things are not as they should be, and to have the communication skills and patience necessary to convince others of the correct course of action.
Whether or not our future foresters will be able to realize this ideal depends on many things: the ability of forestry schools to train them how to communicate well and discuss issues of professional responsibility effectively, the awareness and support of the general public on forest issues, and of course, the willingness of professional associations to help create the climate for enhancing the influence and visibility of the profession. Tall orders indeed, but necessary if a new legacy is to be created that harnesses the youthful enthusiasm of today's students for tomorrow's forests.

\section{References}

Miller, Alan. 1982. Environmental problem-solving; psychosocial factors. Envirn. Manag. 6: 535-541.

Swift, Jamie. 1983. The MacAlpine case, power versus ethics in the forests. Harrowsmith Oct. \& Nov:: 38-45, 107-112.

Teeguarden, Dennis E. 1984. What forestry students believe. J. For. 82: $539-545$.

Wenner, Lambert N. 1986. The practice and promise of social science in the Forest Service. First Nat. Symp. on Social Sci., in Resour. Manag., Oregon State Univ., Corvallis. Unpub. U.S.D.A. For. Serv. Pap.

\section{TIMMERLINN}

PROFESSIONAL AND TECHNICAL SERVICES

IN FORESTRY AND ENVIRONMENTAL SCIENCES

R.R. No. 2, STE. AGATHE DES MONTS, QUE. J8C $2 Z 8$ 